\title{
Practical context of enzymatic treatment for wound healing: A secreted protease approach (Review)
}

\author{
MARÍA ISABELA AVILA-RODRÍGUEZ ${ }^{1}$, DAVID MELÉNDEZ-MARTÍNEZ ${ }^{1}$, CUAUHTEMOC LICONA-CASSANI ${ }^{1}$, \\ JOSÉ MANUEL AGUILAR-YAÑEZ ${ }^{1,2}$, JORGE BENAVIDES ${ }^{1}$ and MIRNA LORENA SÁNCHEZ ${ }^{3}$ \\ ${ }^{1}$ Tecnologico de Monterrey, Escuela de Ingeniería y Ciencias, Monterrey, Nuevo León 64849; ${ }^{2}$ Scicore Medical SAPI de CV, \\ Monterrey, Nuevo León 64920, Mexico; ${ }^{3}$ Laboratorio de Materiales Biotecnológicos, Departamento de Ciencia y Tecnología, \\ Universidad Nacional de Quilmes-Imbice-Conicet-Cicpba, Bernal, Buenos Aires B1876BXD, Argentina
}

Received October 1, 2019; Accepted February 14, 2020

DOI: $10.3892 /$ br. 2020.1300

\begin{abstract}
Skin wounds have been extensively studied as their healing represents a critical step towards achieving homeostasis following a traumatic event. Dependent on the severity of the damage, wounds are categorized as either acute or chronic. To date, chronic wounds have the highest economic impact as long term increases wound care costs. Chronic wounds affect 6.5 million patients in the United States with an annual estimated expense of $\$ 25$ billion for the health care system. Among wound treatment categories, active wound care represents the fastest-growing category due to its specific actions and lower costs. Within this category, proteases from various sources have been used as successful agents in debridement wound care. The wound healing process is predominantly mediated by matrix metalloproteinases (MMPs) that, when dysregulated, result in defective wound healing. Therapeutic activity has been described for animal secretions including fish epithelial mucus, maggot secretory products and snake venom, which contain secreted proteases (SPs). No further alternatives
\end{abstract}

Correspondence to: Dr Mirna Lorena Sánchez, Laboratorio de Materiales Biotecnológicos, Departamento de Ciencia y Tecnología, Universidad Nacional de Quilmes-Imbice-Conicet-Cicpba, Roque Sáenz Peña 352, Bernal, Buenos Aires B1876BXD, Argentina E-mail:mirna.sanchez@unq.edu.ar

Dr Jorge Benavides, Tecnologico de Monterrey, Escuela de Ingeniería y Ciencias, Av. Eugenio Garza Sada 2501 sur, Monterrey, Nuevo León 64849, México

E-mail: jorben@tec.mx

Abbreviations: ECM, extracellular matrix; FMC, fish mucus cathepsin; FMM, fish mucus meprins; FMMPs, fish matrix metalloproteinases; FMSP, fish mucus serine proteases; MaPs, maggot proteases; MMPs, matrix metalloproteases; SPs, secreted proteases; SVMPs, snake venom metalloproteases; SVSPs, snake venom serine proteinases; TGF- $\beta 1$, transforming growth factor- $\beta 1$; VEGF, vascular endothelial growth factor

Key words: enzymatic wound treatment, fish epithelial mucus, maggot secretory products, matrix metalloproteases, snake venom proteases for use, sources or types of proteases used for wound healing have been found in the literature to date. Through the present review, the context of enzymatic wound care alternatives will be discussed. In addition, substrate homology of SPs and human MMPs will be compared and contrasted. The purpose of these discussions is to identify and propose the stages of wound healing in which SPs may be used as therapeutic agents to improve the wound healing process.

\section{Contents}

1. Introduction

2. Chronic wound healing management: Practical context of traditional and enzymatically based debridement approaches

3. MMPs in skin wound healing: Comparison and substrate homology with proteases secreted from other animals

4. Potential of SPs as novel alternatives for wound healing care

5. Future perspectives

\section{Introduction}

A wound of the skin is generally described as the interruption of the epithelial surface caused by a physical or thermal challenge (1). Skin wounds have been extensively studied as their healing represents a critical step in achieving homeostasis following a traumatic event. Dependent on the severity of the damage, wounds are categorized into either acute or chronic (2). To date, chronic wounds have the highest economic impact as long term treatment increases wound care costs (3). It is estimated that $1-2 \%$ of the population of the developing world will experience a chronic wound in their lifetime (4). According to Brem et al (5), in 2007 chronic wounds had affected 6.5 million patients in the United States, with an annual estimated health care expense of $\$ 25$ billion (6). However, to date, the actual cost of chronic wound care in the United States is unknown (7). There has been a relatively high increase in the incidence of chronic wounds, and this may be closely associated with the increase in factors which impair wound healing, such as diabetes, obesity, or therapeutics such as chemotherapy, steroids and non-steroidal anti-inflammatory drugs (6). 
The cost of chronic wound care represents a complicated scenario for patients and health care systems, leading to a necessity for the development of healing solutions which are both quicker and more cost-effective. To date, the available wound treatment therapeutics are: dressings, such as antimicrobial, films and alginate; hydrocolloids, collagen products, gauze composites and hydrogels; and active wound care (8). Active wound care represents the fastest growth category (20.6\% compound annual growth rate between 2016-2022) as it is an alternative that has a more specific action and is more cost-effective (9). Within the active wound care category, proteases from a range of sources have been employed as successful agents in debridement (10), enhancing wound healing (11), coagulation (12) and keloid scar treatments (13). Of these, debridement comprises the principal dermatological application in enzymatic wound care, a proven and well-established principle (14).

The wound healing process is predominantly mediated by matrix metalloproteinases (MMPs) (15-17). Dysregulation of MMPs results in defective wound healing, which has made them targets of study in cases of chronic wounds, diabetic foot injury, keloid healing and burned skin (10). The topical application of non-human proteases has demonstrated beneficial therapeutic effects in events where MMPs fail due to dysregulation, for example in hemostasis (18), wound closure (19) and debridement (20).

Debridement is the most widely explored enzymatic wound care application, in which the most frequently used proteases are collagenases, serine proteases and cysteine proteases. The therapeutic activity of animal secretions from fish epithelial mucus (21), maggot (Lucilia sericata) secretory products (22) and snake venom (23) have also been demonstrated. These secretions contain different types of proteases capable of degrading the same substrates as MMPs. Besides these, no further use cases, sources or types of proteases for wound healing were found based on the currently available literature.

Through the present review, the context of enzymatic wound care alternatives will be discussed, along with a comparison of substrate homology of secreted proteases (SPs) and human MMPs. This review will aid in the identification of which stages of the wound healing process SPs may be used as therapeutic agents.

\section{Chronic wound healing management: Practical context of traditional and enzymatically based debridement approaches}

Debridement is the first step to enhance repair of chronic wounds. According to the European Wound Management Association, this procedure is considered a basic necessity to induce the physiological process of tissue repair (24). Through debridement, necrotic tissue is removed by external means to create a stable and healthy scaffold for re-epithelialization (25). In healthy individuals under normal circumstances, debridement is performed naturally following clot formation by neutrophil-derived MMPs and other components (26). However, when the MMP machinery fails, there is an accumulation of devitalized tissue. As a consequence, the steadiness of prolonged catabolism diminishes re-epithelialization and results in chronic wounding (27).
This failure represents an important baseline to treat chronic wounds, as devitalized epithelium builds up a physical barrier that precludes the healing process by interfering with the repair machinery, mimicking signs of infection, providing nutrients to anaerobic pathogenic agents, such as Clostridium perfringens or Bacteroides sp., and promoting cytokine production that in severe cases generates a septic response (28).

Debridement can be performed through autolytic, surgical, biological or enzymatic means (28). Of these, autolytic debridement is the most conservative treatment strategy. It enhances the action of endogenous phagocytic cells and proteases such as MMPs through dressings that provide the ideal catalytic conditions for removal of necrotic tissue (29). Among the dressings available for autolysis, films (polydimethylsiloxane), gauzes, hydrocolloids, hydrogels, alginates, hydrofibers and foams have been proposed $(25,30)$. This strategy is selective, painless, inexpensive and suitable for most types of wounds (31). However, this process is slow, dependent on suitable reaction conditions and on the physiological response of the patient, and carries the risk of skin degradation due to prolonged exposure to moisture (maceration) (32) within the surrounding skin (28).

Surgical debridement strategies are performed by excising necrotic tissue until only healthy skin regions are exposed (33). Available variants of surgical debridement include ultrasound debridement, plasma-mediated bipolar radio-frequency ablation, versa-jet (fluid jet technology) and hydrosurgery $(34,35)$. Surgical debridement is the fastest and most effective route of treatment, but is an expensive method that requires a sterile surgical environment, trained practitioners, and specific instruments, and is contraindicated for patients with clotting disorders $(28,36)$.

By contrast, biological debridement promotes the removal of devitalized epithelium through the digestive action of Lucilia sericata sterile maggots (31). Maggots are caged in wound-sized hydrocolloid dressings that are placed in the affected area (37). The secretion of several components including proteolytic enzymes, such as trypsin and chymotrypsin serine proteases, then catalyze non-viable skin into a liquid feedstock that facilitates maggot feed (38). This alternative has proved to be efficient in several types of chronic wounds (39) and ulcers $(40,41)$ by providing quick wound debridement, reduction in the use of biofilms, disinfection from bacteria (40,42-45) and improved pain control (46). However, due to the negative image several societies impose on maggots, this alternative has not been well accepted by patients and practitioners (47). Furthermore, it is contraindicated for the treatment of fistulae, exposed vessels and wounds in proximity to vital organs (42).

A potential compromise is enzymatic debridement, in which proteases from different sources (bacterial, vegetal or animal) is applied to the wounded area to remove necrotic tissue $(48,49)$. Enzymatic debridement is selective and suitable for infected wounds (36), without the need for complex equipment or application procedures. This alternative also takes less time and requires fewer applications to accomplish debridement compared with dressings used for autolytic treatments (50). Other reported enzymatic wound healing approaches are anti- or pro-coagulation through venom toxins 
from Bothrops sp. $(51,52)$. These enzymes may frequently be inhibited by salts, temperature and hydrogen peroxide, which are common elements of aseptic solutions. A stinging sensation and exudate may also be observed as an after-effect of enzymatic treatment (36).

From these four mentioned alternatives, three are directly dependent on proteases to perform the debriding activity. The direct or indirect use of proteases is therefore the second most commonly used tool after surgical debridement. In the current literature, the most commonly used proteases in direct enzymatic debridement are bromelain, papain and bacterial collagenases (53). Other enzymes have been demonstrated to intervene as anti- or pro-coagulation agents and in non-specific wound healing from animal secretions. The most common commercially and non-commercially available proteases associated with wound healing are listed in Table I.

Animal secretions with high quantities of protease content, including fish epithelial mucus and snake venom, have been reported to enhance wound healing. Wound healing properties were reported for the secreted mucus of the fish species Netuma barba (54), Channa striatus (55) and Clarias gariepinus (56). A reduction in healing time of almost $60 \%$ was achieved following the topical application of mucus preparations in the wounds of mice, rats, guinea pigs and humans (57). For snake venom, anti- or pro-coagulation and epithelial cell migration properties were observed with the toxins from the venom of Bothrops moojeni, B. atrox (51), B. alternatus (18) and B. jararaca (58).

Thus far, the primary application of proteases in wound treatment has been debridement. Information regarding the use of proteases being used for other wound healing treatments is scarce, suggesting that relatively little attempt has been made to propose the use of proteases in different stages of the wound healing process $(57,59)$. Several therapeutic benefits have been described from animal secretions, but studies on their possible use in wound healing stages are limited. It may be beneficial to determine whether the existing types of SPs present in animal secretions with reported therapeutic effects (maggots, fish and snakes), can mimic human MMPs.

\section{MMPs in skin wound healing: Comparison and substrate homology with proteases secreted from other animals}

Wound healing is the process by which an epithelial discontinuity is closed and is divided into four major steps: Hemostasis, inflammation, cell migration-proliferation and skin remodeling $(60,61)$. The interaction and co-ordination of several elements such as cytokines, growth factors, coagulation elements, extracellular matrix (ECM) components, parenchymal cells and MMPs $(62,63)$ enable the correct progression of these major steps (Fig. 1).

It has been reported that MMPs predominantly mediate the wound healing process and are involved in several events in each stage, including ECM degradation (64), cell proliferation/migration, mesenchymal cell differentiation (65), wound contraction, angiogenesis and re-epithelialization (66-68). At present, 25 different MMP variants have been identified in the human genome $(64,69)$. Of these, 11 are responsible for skin remodeling and wound healing (Table II).
The presence of SPs has been reported in the secretions of fish (70), maggots $(71,72)$ and snake venom (73). As MMPs are one of the primary participants of the wound healing process, a similarity may exist in the catalytic mechanisms of SPs and MMPs. This similarity may explain the therapeutic effect provided by these secretions.

Maggot therapy efficiency in the treatment of necrotic, infected chronic wounds is due to the activity of several SPs. This secretion consists of serine proteases (trypsin-like and chymotrypsin-like) and metalloproteases (71,72). As a secretion, maggot proteases (MaPs) contribute to the wound healing process, primarily in fibroblast stimulation and bacterial disinfection. MaPs degrade fibrin clots and fibronectin (74), enhancing fibroblast metabolism and migration $(22,75)$. In addition, MaPs increase TGF- $\beta$ (transforming growth factor- $\beta$ ) signaling in wounds treated with maggots (76), which enhances endothelial cell and keratinocyte migration, thus promoting wound closure. Furthermore, MaPs inhibit neutrophil migration and decrease the production of pro-inflammatory mediators in neutrophils and monocytes $(44,77)$, leading to recruitment of pro-angiogenic growth factors (78) and healthy granulation tissue (79). MaPs are also considered antimicrobial enzymes (80), capable of eliminating Staphylococcus aureus and Pseudomonas aeruginosa $(44,81)$ as well as degradation of biofilms produced by S. epidermidis and S. aureus (41).

From MaPs, only a chymotrypsin-like protease has been isolated from maggot secretions, which exhibited clotting and proteolytic activity in fibronectin, suggesting its use in hemostasis and for temporary collagen-rich replacement of $\operatorname{ECM}(74,82)$. These proteases also reduce biofilms in patients with leg ulcers $(40,41)$.

Similar to maggot secretions, fish mucus and snake venom have been hypothesized as wound healing treatment agents. In traditional medicine, they have been used as a therapy for skin burns and hemostasis $(51,55,56,83)$. Fish epithelial mucus consists primarily of glycoproteins and immune biomolecules (84). Immune components, metalloproteases, serine proteases, and cathepsins B, D and L, have been identified in fish epithelial mucus $(85,86)$. Enzymatic components from crude secretions contribute to accelerated clot formation and agglutination of red cells (87).

In the case of metalloproteases, fish matrix metalloproteinases (FMMPs) 9 and 13 and fish mucus meprins (FMM) have been described as components of fish mucosal secretions $(88,89)$. FMMPs 9 and 13 have analogous variants in human tissue, which participate in wound contraction and re-epithelialization $(66,90)$. FMMs can degrade collagen IV, fibrillar procollagen and fibronectin (91-93), which are also degraded by MMPs 3, 10, 11 and 12 (Table II). These proteases are involved in wound contraction, monocyte/macrophage metabolism and re-epithelialization (66).

Cathepsins are a family of proteases that have been identified in fish epithelial mucus, and these cathepsins in fish mucus have not been characterized. It is hypothesized that the cathepsins in fish mucus may exhibit a therapeutic effect on wound healing based on the available data regarding their properties on human skin. These proteases are normally present in lysosomal vesicles, but their presence has also been demonstrated extracellularly (94). In human physiology, they participate in wound healing during hemostasis (95), ECM 
Table I. Applications of proteases in wound healing treatments classified by their reported therapeutic effect.

A, Debridement and skin burns

\begin{tabular}{|c|c|c|c|}
\hline Author, year & Enzyme & Source & (Refs.) \\
\hline Ford et al, 2006 & Papain + urea (Accuzyme SE) & Carica papaya & $(152)$ \\
\hline Ford et al, 2006 & $\begin{array}{l}\text { Papain, Urea, Chlorophyllin Copper } \\
\text { Complex Sodium (Panafil SE) }\end{array}$ & & $(152)$ \\
\hline $\begin{array}{l}\text { Muhammad et al, 2014; } \\
\text { Yaakobi et al, } 2007\end{array}$ & Papain/Chymopapain & & $(20,153)$ \\
\hline Klasen, 2000 & Collagenase & Clostridium sp. & (14) \\
\hline Smith \& Nephew, Inc., 2014 & Collagenase $\left(\right.$ Santyl ${ }^{\circledR}$ ) & C. histolyticum & $(154)$ \\
\hline Giudice et al, 2017 & Bromelain (NexoBrid) & Ananas comosus & $(155)$ \\
\hline Gorecki and Toren, 2005 & Bromelain cysteine protease & & $(156)$ \\
\hline Klein and Houck, 1980 & Bromelain cysteine protease & & $(157)$ \\
\hline Niehaus et al, 2012 & Debrilase & Lucilia sericata & $(158)$ \\
\hline Niehaus et al, 2012 & Serine protease & & $(159)$ \\
\hline Rosenberg, 2012 & $\begin{array}{l}\text { Bromelain, trypsin enzyme } \mathrm{H}-4 \text {, collagenase, } \\
\text { papain/papain-urea }\end{array}$ & Several & $(160)$ \\
\hline Freeman et al, 2012 & $\begin{array}{l}\text { Collagenase, elastase, papain, bromelain, } \\
\text { hydrolase, streptokinase }\end{array}$ & & $(161)$ \\
\hline
\end{tabular}

$\mathrm{B}$, Anticoagulation and procoagulation

\begin{tabular}{|c|c|c|c|}
\hline Author, year & Enzyme & Source & (Refs.) \\
\hline Waheed et al, 2017 & Moojenin (Defibrase ${ }^{\circledR}$ ) & Bothrops moojeni & $(51)$ \\
\hline Waheed et al, 2017 & Batroxobin (Reptilase) & B. atrox & $(51)$ \\
\hline Chan et al, 2016 & $\begin{array}{l}\text { Thromboplastin-like and thrombin-like } \\
\text { (Hemocoagulase) }\end{array}$ & & $(52)$ \\
\hline De Marco Almeida et al, 2015 & Venom & B. alternatus & $(18)$ \\
\hline Yaakobi et al, 2004 & Collagenase & Non specified & $(162)$ \\
\hline Rodeheaver et al, 1974 & Trypsin/ADAMS SVMP & Bovine & $(163)$ \\
\hline Glyantsev et al, 1996 & Collagenase & Crab (specie non specified) & $(27)$ \\
\hline Ferreira et al, 2017 & Buffalo cryoprecipitate and Serine protease & Crotalus durissus terrificus & $(59)$ \\
\hline
\end{tabular}

C, Enhancing wound healing

\begin{tabular}{lll}
\hline Author, year & \multicolumn{1}{c}{ Enzyme } & Source \\
\hline Fierro-Arias et al, 2017 & Collagenase & C. histolyticum \\
Gao et al, 2015 & rMMP8 and MMP9 inhibitor & Non specified \\
Pasha et al, 2015 & Cream/composite & Channa striatus \\
Rilley and Herman, 2005 & Collagenase & Clostridium sp. \\
Ferreira et al, 2018 & Jararhagin & B. jararaca \\
Mukherjee et al, 2017 & Mucus & Echinoida sp. \\
Costa-Neto, 2004 & Globe eye & Netuma barba \\
Manan Mat Jais, 2007 & Mucus & C. striatus \\
\hline
\end{tabular}

MMP, matrix metalloproteinase; SVMP snake venom metalloprotease; rMMP, recombinant MMP.

remodeling (96) and keratinocyte migration (97). Cathepsin- $\mathrm{L}$ substrate affinity has been described for laminins, fibronectin, elastin and collagen $(98,99)$. Cathepsin-D has affinity for fibronectin, proteoglycans, and collagens I and II (100), while substrate affinity of Cathepsin-B has been described primarily for collagen II, IX and XI (101). These substrates are also 


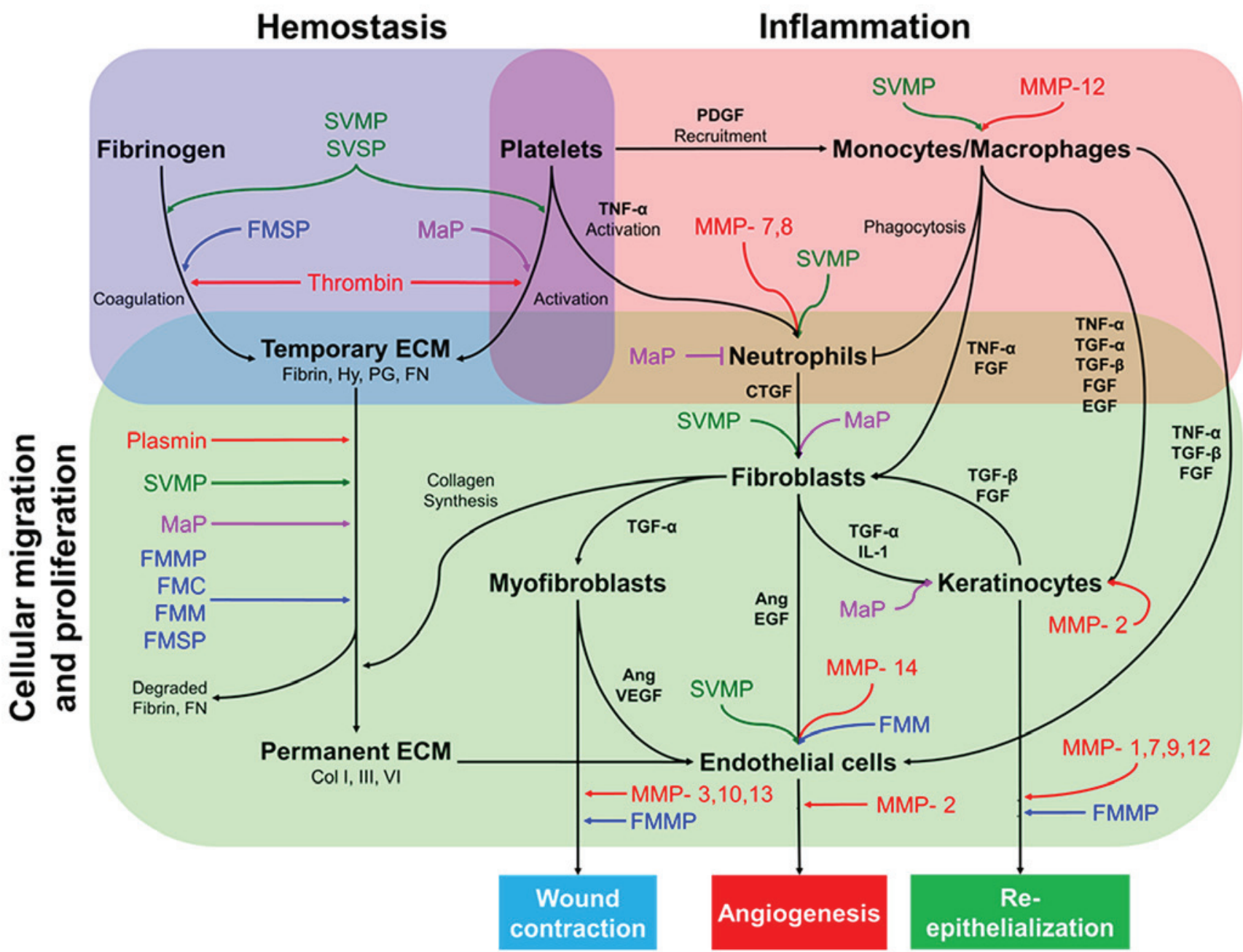

Figure 1. Simplified diagram of the interactions between different cell types during wound healing, the contribution of MMPs and proposed wound healing mechanisms of SPs. Skin injury repair begins with hemostasis, a process which stops blood loss and provides a temporary matrix facilitating further steps in wound healing. Fibrin-rich ECM formation stimulates neutrophil-activated monocyte recruitment through TNF- $\alpha$ and PDGF. Both neutrophils and monocytes produce several growth factors, such as TNF- $\alpha$, TGF- $\alpha$, TGF- $\beta$, EGF and FGF, to enhance migration and proliferation of fibroblasts, endothelial cells, and keratinocytes to the site of injury. Fibroblasts stimulate other cells to produce collagen deposits in the ECM, wound contraction, angiogenesis and re-epithelization. Studies suggest that SPs, such as FMC, FMMP, FMM, FMSP, MaP, SVMP and SVSP, may behave similarly to endogenous MMPs during these stages. Ang, angiopoietin; CTGF, connective tissue growth factor; Col, collagen; ECM, extracellular matrix; EGF, epidermal growth factor; FGF, fibroblast growth factor; FMC, fish mucus cathepsin; FMMP, fish mucus matrix metalloprotease; FMM, fish mucus meprin; FMSP, fish mucus serine protease; FN, fibronectin; Hy, hyaluronan; IL-1, interleukin-1; MaP, maggot protease; MMP, matrix metalloproteinase; PDGF, platelet-derived growth factor; PG, proteoglycan; SVMP, snake venom metalloprotease; SVSP, snake proteinase; TGF, transforming growth factor; TNF- $\alpha$, tumor necrosis factor- $\alpha$; VEGF, vascular endothelial growth factor.

target proteins for MMPs $1,8,13$ and $14(66,102)$, which supports the reported role of cathepsins in wound contraction and hemostasis.

Additionally, fish mucus serine proteases (FMSPs) are present in mucosal secretions (103), albeit with only poor substrate characterization thus far. Nevertheless, this family of proteases has reported activity on collagen, elastin, fibrin and fibrinogen $(104,105)$. Thus, this protease may be useful during hemostasis, generating platelet aggregation and fibrin clot formation (106). Additionally, FMSPs degrade fibrin, which may assist in the change of ECM from temporary to collagen-rich, resulting in cellular proliferation and migration (107). This family of enzymes also interferes with the maturation of MMPs (66) and the desquamation processes (108).

Snake venoms, particularly from the Viperidae family, are rich in proteases. There secretion is comprised of two types of proteases: Snake venom metalloproteases (SVMPs) and snake venom serine proteinases (SVSPs) (73). These enzymes catalyze a broad range of ECM components, coagulation factors and proteins involved in platelet aggregation $(109,110)$.

SVMPs can intervene in hemostasis, as these hydrolyze glycoprotein $\mathrm{Ib}$ and factor $\mathrm{X}$, which promote coagulation (110-112) and platelet aggregation $(113,114)$, respectively. During inflammation, SVMPs enhance the infiltration of inflammatory cells $(115,116)$ as well as increasing neutrophil and macrophage numbers (117-119), which increases soluble collagen levels and enhances angiogenesis through increasing vascular endothelial growth factor (VEGF) and TGF- $\beta 1$ release (58). During cell migration and proliferation, it has been demonstrated that SVMPs degrade fibrin and fibronectin $(112,120)$, resulting in the change from temporary to collagen-rich ECM. SVMPs also activate migration of skin fibroblasts (121) and endothelial cells (111,122-124). In 


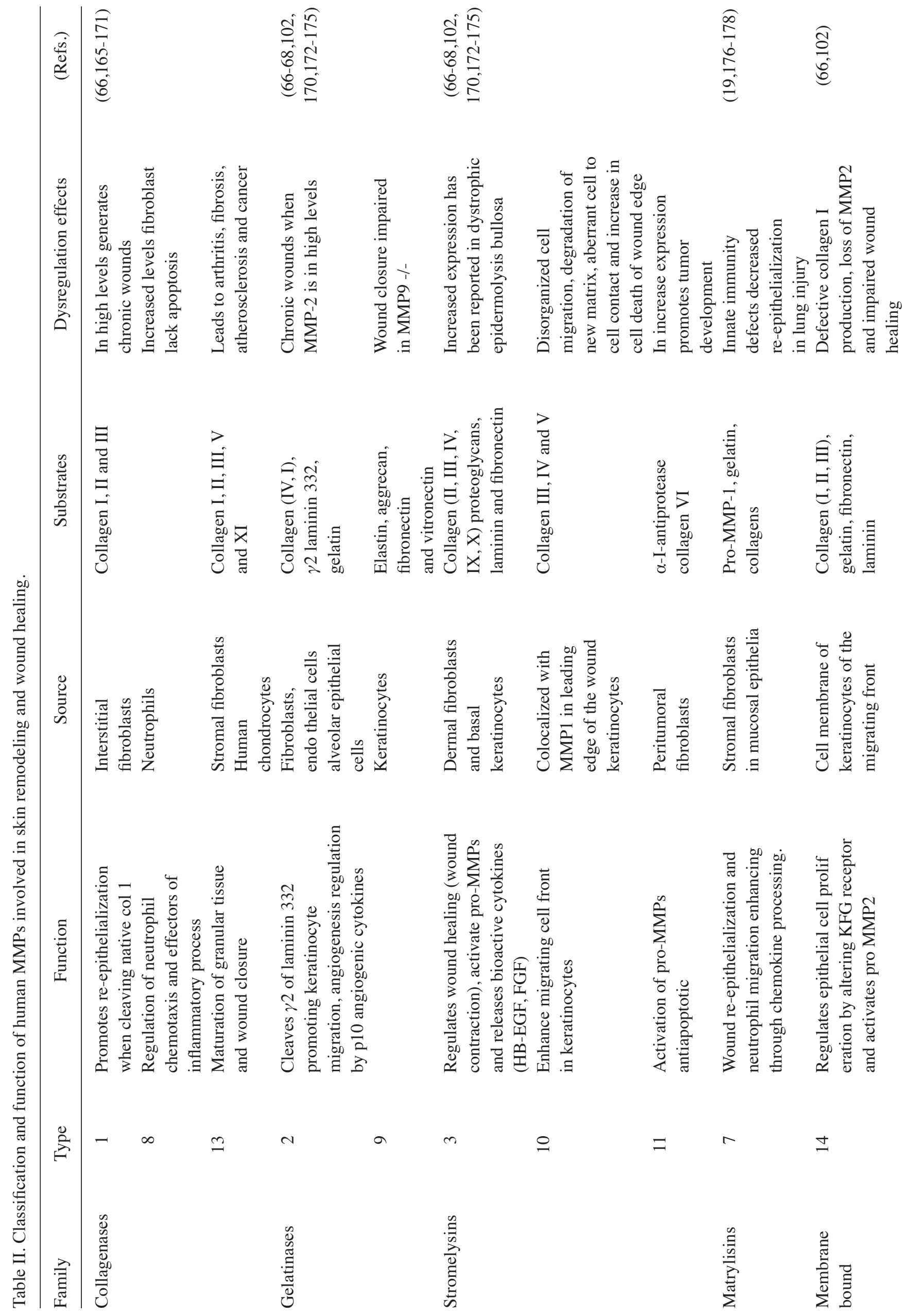


addition, SVSPs exhibit proteolytic activity on Factor V and fibrinogen, promoting fibrin clot formation (125-127). SVSPs also promote aggregation of platelets (128).

Following analysis of reported interventions of SPs in wound healing, it could be presumed that they can intervene as helpers in several intermediate steps of the wound healing processes including coagulation, ECM degradation for re-epithelialization, or wound contraction, among other steps. The hypothesized mechanisms of SPs during the process of wound healing are presented in Fig. 1. Study of these variants may assist in the development of novel specific alternatives for active chronic wound healing care.

\section{Potential of SPs as novel alternatives for wound healing care}

Substrate homology analysis among MMPs and SPs suggest that animal enzymes may act similarly to the ones physiologically present in human skin. As presented in Fig. 1, previously compared SPs may be used to facilitate several steps involved in the process of wound healing, or to compensate for the physiological variants when they do not function properly. To understand this from a clearer perspective, it is important to comprehend in which of the most common chronic wounds types SPs may serve as suitable co-adjuvants.

In the current literature, chronic wounds have been classified into pressure ulcers, venous ulcers or diabetic ulcers $(129,130)$. Pressure ulcers are caused by pressure, shear force, friction or a combination of these (131). The prevention and cure of pressure ulcers is associated with daily movement of extremities and frequent body positioning during hospitalization (132). In this case, the use of proteases may serve as palliative care in bed preparation for wounded patients as opposed to assisting the metabolic processes of wound healing.

Chronic venous ulcers are associated with inflammation, mechanical damage and erratic structural remodeling of the vein. Pathological hemodynamics results in changes to microcirculation; this produces thrombosis, proinflammatory activity and impaired MMP-3 activity (133), leading to cell dysfunction and finally to ulceration (134). For ulceration and potential necrosis, maggot therapy has shown efficacy $(40,41)$ by decreasing inflammation and neutrophil migration $(77,135)$. It also degrades eschar, debrides the wound and serves as a bacterial disinfectant $(40,42-45)$. Furthermore, fish mucus proteases have been shown to exhibit antibacterial activity $(55,136)$, which may be useful for bacterial disinfection of ulcers.

Diabetic foot ulcers are wounds that manifest after a cascade of metabolic dysregulations initiated by long-term hyperglycemia (137). As a result of prolonged exposure to high blood sugar levels, there is a decrease in fibrinolytic activity, thus increasing blood viscosity and coagulation in this type of wound (138). In addition, hyperglycemia results in a reduction of growth factors and receptor levels (such as TGF- $\beta 1$ ), accompanied by a prolonged inflammatory phase due to upregulation of MMP-9 $(139,140)$, which interrupts the inflammatory and proliferative phases of wound healing (141).

As an alternative therapy for diabetic foot ulcers, maggot treatment has demonstrated improved efficacy and efficiency compared with conventional methods (142). Furthermore, 
MaPs (74), FMMPs (91) and a certain type of SVMP $(112,120)$ have been reported to exhibit fibrinolytic activity which may ameliorate the characteristic viscosity of diabetic ulcers. Additionally, it has been reported that TGF- $\beta$ signaling is increased in the presence of MaPs (76) and SVMPs (58), and this may also assist wound healing in this type of ulcer. However, certain SVMPs can promote coagulation (110-112,120); thus, meticulous care must be taken to separate and study each component embedded within the secretion instead of applying it as a whole.

In another report, fish mucus application enhanced the healing of laparotomy wounds (143). Therefore, SPs may be used to reduce the time taken for wound healing or for the removal of necrotic tissue, depending on the wound pathophysiology.

Despite the positive effects of SPs in wound healing, further research must be performed to determine the specific mechanisms of action, regulation, site delivery and bioavailability of proposed proteases before they may be recommended as feasible pharmacological candidates for treatment of chronic wounds. The application of SPs may be limited however, as its use for treatment of burn wounds exhibits highly variable results in patients (14).

It is also important to determine how SPs may affect other wound healing mechanisms when used as an adjuvant with other healing methods such as skin transplants. In this procedure, lost skin is covered with healthy tissue or artificial composites $(144,145)$ that provide the necessary elements (cells, growth factors, MMPs and scaffolds) for the healing process (146). The success of a skin transplant is primarily dependent on angiogenesis between the skin graft and the injury, which is predominantly mediated by MMP-2, 9 and 14 (147). Thus, SPs have been proposed as potential adjuvants to increase tissue compatibility during skin transplants.

Nevertheless, studies on SP-aided transplants is still ambiguous. For example, the use of botulinum toxin A during skin transplantation in murine models enhances the expression of VEGF and prolonged the survival of skin grafts (148). By contrast, Kucukkaya et al (149) demonstrated that the same toxin reduces wound-graft contraction. Thus, the effects of SPs on skin transplants requires additional studies to determine its benefits during skin transplantation.

\section{Future perspectives}

Studies and development of less expensive wound healing treatment alternatives must be encouraged. Treatment of all types of even the most common chronic wounds still incur a high cost, and the reported care expenses are $\$ 50,000$ for a diabetic ulcer (25), $\$ 500-\$ 70,000$ dollars for a pressure ulcer (150) and $\$ 390-\$ 50,967$ dollars per venous ulcer (151). The proposal of proteases obtained from animal secretions is a promising area to explore, as these act on specific substrates involved in the wound healing process. Furthermore, it is important to determine the molecular events specific to each chronic wound case, as these may represent key tags on how the proposed SPs may intervene. Under these conditions, active wound care represents a viable solution if its use is based on specific requirements. Importantly, SP characterization is crucial to dispense with the use of secretions in wound repair, and instead use only the SPs. This may also allow heterologous production, immobilization or improvement of the therapeutic properties of the characterized SPs through mutagenesis. In addition, time-efficient diagnostic tests on for detection of molecular targets in skin wound healing may be developed to guide practitioners on which tool to use for chronic wound care, resulting in improved wound healing and thus restoration of homeostasis.

\section{Acknowledgements}

Not applicable.

\section{Funding}

The present study was funded by CONACYT (grant nos. 886264 and 548216).

\section{Availability of data and materials}

Not applicable.

\section{Authors' contributions}

All authors (MIAR, DMM, CLC, JMAY, JB and MLS) contributed to writing, editing and revising the manuscript. All authors approved the final version of the manuscript.

\section{Ethics approval and consent to participate}

Not applicable.

\section{Patient consent for publication}

Not applicable.

\section{Competing interests}

The authors declare that they have no competing interests.

\section{References}

1. Dhivya S, Padma VV and Santhini E: Wound dressings-a review. Biomedicine (Taipei) 5: 22, 2015.

2. Nicoli Aldini N, Fini M and Giardino R: From Hippocrates to tissue engineering: Surgical strategies in wound treatment. World J Surg 32: 2114-2121, 2008.

3. Sen CK: Human wounds and its burden: An updated compendium of estimates. Adv Wound Care (New Rochelle) 8: 39-48, 2019.

4. Järbrink K, Ni G, Sönnergren H, Schmidtchen A, Pang C, Bajpai R and Car J: Prevalence and incidence of chronic wounds and related complications: A protocol for a systematic review. Syst Rev 5: 152, 2016.

5. Brem H, Stojadinovic O, Diegelmann RF, Entero H, Lee B, Pastar I, Golinko M, Rosenberg H and Tomic-Canic M: Molecular markers in patients with chronic wounds to guide surgical debridement. Mol Med 13: 30-39, 2007.

6. Anderson K and Hamm RL: Factors that impair wound healing. J Am Coll Clin Wound Spec 4: 84-91, 2014.

7. Nussbaum SR, Carter MJ, Fife CE, DaVanzo J, Haught R, Nusgart $M$ and Cartwright $D$ : An economic evaluation of the impact, cost, and medicare policy implications of chronic nonhealing wounds. Value Health 21: 27-32, 2018.

8. Avila Rodríguez MI, Rodríguez Barroso LG and Sánchez ML: Collagen: A review on its sources and potential cosmetic applications. J Cosmet Dermatol 17: 20-26, 2018. 
9. Malik M: Advanced wound care market by product type (Infection Management, Exudate Management, Active Wound Care, Therapy Devices), application (Chronic Wounds and Acute Wounds), end user (Hospitals and Community Centers)-global opportunity analysis and industry forecast, 2014-2022, 2016.

10. Khan W and Morgan-Jones R: Debridement: Defining something we all do. J Trauma Orthop 4: 48, 2016.

11. Kwan SH and Ismail MN: Identification of the potential bio-active proteins associated with wound healing properties in snakehead fish (Channa striata) mucus. Curr Proteomics 15: 299-312, 2018.

12. Fatima $L$ and Fatah C: Pathophysiological and pharmacological effects of snake venom components: Molecular targets. J Clin Toxicol 4: 190, 2014.

13. Fierro-Arias L, Campos-Cornejo NG, Contreras-Ruiz J, Espinosa-Maceda S, López-Gehrke I, Márquez-Cárdenas R, Ramírez-Padilla M, Veras-Castillo E and Rodríguez-Alcocer AN Productos enzimáticos (hialuronidasa, colagenasa y lipasa) y su uso en dermatología. Dermatol Rev Mex 61: 206-219, 2017.

14. Klasen HJ: A review on the nonoperative removal of necrotic tissue from burn wounds. Burns 26: 207-222, 2000.

15. Gill SE and Parks WC: Metalloproteinases and their inhibitors: Regulators of wound healing. Int J Biochem Cell Biol 40: 1334-1347, 2008.

16. Ayuk SM, Abrahamse $\mathrm{H}$ and Houreld NN: The role of matrix metalloproteinases in diabetic wound healing in relation to photobiomodulation. J Diabetes Res 2016: 2897656, 2016.

17. Mclennan SV, Min D and Yue DK: Matrix metalloproteinases and their roles in poor wound healing in diabetes. Wound Pract Res 16: 116-120, 2008.

18. De Marco Almeida F, de Castro Pimenta AM, Oliveira MC and De Lima ME: Venoms, toxins and derivatives from the Brazilian fauna: Valuable sources for drug discovery. Sheng Li Xue Bao 67 261-270, 2015

19. Riley KN and Herman IM: Collagenase promotes the cellular responses to injury and wound healing in vivo. J Burns Wounds 4: e8, 2005 .

20. Muhammad I, Shaikh SA and Rashid HU: Role of papaya dressings in the management of diabetic foot ulcers. J Rawalpindi Med College 18: 87-89, 2014.

21. Esteban MÁ: An overview of the immunological defenses in fish skin. ISRN Immunol 2012: 853470, 2012

22. Horobin AJ, Shakesheff KM and Pritchard DI: Maggots and wound healing: An investigation of the effects of secretions from Lucilia sericata larvae upon the migration of human dermal fibroblasts over a fibronectin-coated surface. Wound Repair Regen 13: 422-433, 2005

23. Rajesh R, Raghavendra Gowda CD, Nataraju A, Dhananjaya BL, Kemparaju K and Vishwanath BS: Procoagulant activity of Calotropis gigantea latex associated with fibrin(ogen)olytic activity. Toxicon 46: 84-92, 2005.

24. White R: The costs of wound debridement and exudate management. Br J Health Care Manag 21: 172-175, 2015.

25. Han G and Ceilley R: Chronic wound healing: A review of current management and treatments. Adv Ther 34: 599-610, 2017.

26. Sinclair RD and Ryan TJ: Proteolytic enzymes in wound healing: The role of enzymatic debridement. Australas J Dermatol 35: 35-41, 1994.

27. Glyantsev SP, Savvina TV and Zayets TL: Comparative study of proteolytic enzymes used for debridement of purulent wounds. Bull Exp Biol Med 121: 646-650, 1996.

28. Gray D, Acton C, Chadwick P, Fumarola S, Leaper D, Morris C, Stang D, Vowden K, Vowden P and Young T: Consensus guidance for the use of debridement techniques in the UK. Wounds UK 7: 77-84, 2011

29. Atkin L: Understanding methods of wound debridement. Br J Nurs 23: S10-S12, S14-S15, 2014.

30. Dabiri G, Damstetter E and Phillips T: Choosing a wound dressing based on common wound characteristics. Adv Wound Care (New Rochelle) 5: 32-41, 2016.

31. Manna B and Morrison CA: Wond debridement. StatPearls, 2019.

32. Cutting $\mathrm{K}$ and White R: Maceration of the skin and wound bed. 1: Its nature and causes. J Wound Care 11: 275-278, 2002.

33. Mahoney J and Ward J: Surgical debridement. In: Surgery in wounds. Téot L, Banwell PE and Ziegler UE (eds.). Springer Berlin Heidelberg, Berlin, Heidelberg, pp67-71, 2004

34. Bekara F, Vitse J, Fluieraru S, Masson R, Runz A, Georgescu V, Bressy G, Labbé JL, Chaput B and Herlin C: New techniques for wound management: A systematic review of their role in the management of chronic wounds. Arch Plast Surg 45: 102-110, 2018
35. Liu W, Ma K, Kwon SH, Garg R, Patta YR, Fujiwara T and Gurtner GC: The abnormal architecture of healed diabetic ulcers is the result of FAK degradation by calpain 1. J Invest Dermatol 137: 1155-1165, 2017.

36. Ayello EA and Cuddigan JE: Debridement: Controlling the necrotic/cellular burden. Adv Skin Wound Care 17: 66-75; quiz 76-78, 2004.

37. Whitaker IS, Twine C, Whitaker MJ, Welck M, Brown CS and Shandall A: Larval therapy from antiquity to the present day: Mechanisms of action, clinical applications and future potential. Postgrad Med J 83: 409-413, 2007.

38. Gray M: Is larval (maggot) debridement effective for removal of necrotic tissue from chronic wounds? J Wound Ostomy Continence Nurs 35: 378-384, 2008.

39. Jordan A, Khiyani N, Bowers SR, Lukaszczyk JJ and Stawicki SP: Maggot debridement therapy: A practical review. Int J Acad Med 4: 21-34, 2018.

40. Brown A, Horobin A, Blount DG, Hill PJ, English J, Rich A, Williams PM and Pritchard DI: Blow fly Lucilia sericata nuclease digests DNA associated with wound slough/eschar and with Pseudomonas aeruginosa biofilm. Med Vet Entomol 26: 432-439, 2012.

41. Harris LG, Nigam Y, Sawyer J, Mack D and Pritchard DI: Lucilia sericata chymotrypsin disrupts protein adhesin-mediated staphylococcal biofilm formation. Appl Environ Microbiol 79: 1393-1395, 2013.

42. Parnés A and Lagan KM: Larval therapy in wound management: A review. Int J Clin Pract 61: 488-493, 2007.

43. Cazander G, Pritchard DI, Nigam Y, Jung W and Nibbering PH: Multiple actions of Lucilia sericata larvae in hard-to-heal wounds: Larval secretions contain molecules that accelerate wound healing, reduce chronic inflammation and inhibit bacterial infection. Bioessays 35: 1083-1092, 2013.

44. van der Plas MJ, Jukema GN, Wai SW, Dogterom-Ballering HC, Lagendijk EL, van Gulpen C, van Dissel JT, Bloemberg GV and Nibbering PH: Maggot excretions/secretions are differentially effective against biofilms of Staphylococcus aureus and Pseudomonas aeruginosa. J Antimicrob Chemother 61: 117-122, 2008.

45. Pritchard DI and Brown AP: Degradation of MSCRAMM target macromolecules in VLU slough by Lucilia sericata chymotrypsin 1 (ISP) persists in the presence of tissue gelatinase activity. Int Wound J 12: 414-421, 2015.

46. Arabloo J, Grey S, Mobinizadeh M, Olyaeemanesh A, Hamouzadeh P and Khamisabadi K: Safety, effectiveness and economic aspects of maggot debridement therapy for wound healing. Med J Islam Repub Iran 30: 319, 2016.

47. Evans H: A treatment of last resort. Nurs Times 93: 62-65, 1997.

48. Ramundo J and Gray M: Enzymatic wound debridement. J Wound Ostomy Continence Nurs 35: 273-280, 2008

49. Madhok BM, Vowden K and Vowden P: New techniques for wound debridement. Int Wound J 10: 247-251, 2013.

50. Ziegler B, Hundeshagen G, Cordts T, Kneser U and Hirche C: State of the art in enzymatic debridement. Plast Aesthet Res 5: 33, 2018.

51. Waheed H, Moin SF and Choudhary MI: Snake venom: From deadly toxins to life-saving therapeutics. Curr Med Chem 24: 1874-1891, 2017.

52. Chan YS, Cheung RCF, Xia L, Wong JH, Ng TB and Chan WY: Snake venom toxins: Toxicity and medicinal applications. Appl Microbiol Biotechnol 100: 6165-6181,2016.

53. Smith RG: Enzymatic debriding agents: An evaluation of the medical literature. Ostomy Wound Manage 54: 16-34, 2008.

54. Costa-Neto EM: Implications and applications of folk zootherapy in the state of Bahia, Northeastern Brazil. Sust Dev 12: 161-174, 2004.

55. Manan Mat Jais A: Pharmacognosy and pharmacology of Haruan (Channa striatus), a medicinal fish with wound healing properties. Bol Latinoam Caribe Plant Med Aromaticas 6: 52-60, 2007.

56. Akunne TC, Okafor SN, Okechukwu DC, Nwankwor SS, Emene JO and Okoro BN: Catfish (Clarias gariepinus) slime coat possesses antimicrobial and wound healing activities. UK J Pharm Biosci 4: 81-87, 2016.

57. Al-Hassan J, Thomson M and Griddle RS: Accelerated wound healing by a preparation from skin of the Arabian gulf catfish. Lancet 321: 1043-1044, 1983.

58. Ferreira BA, Deconte SR, de Moura FBR, Tomiosso TC, Clissa PB, Andrade SP and Araújo FA: Inflammation, angiogenesis and fibrogenesis are differentially modulated by distinct domains of the snake venom metalloproteinase jararhagin. Int $\mathbf{J}$ Biol Macromol 119: 1179-1187, 2018. 
59. Ferreira RS Jr, de Barros LC, Abbade LPF, Barraviera SRCS, Silvares MRC, de Pontes LG, Dos Santos LD and Barraviera B: Heterologous fibrin sealant derived from snake venom: From bench to bedside-an overview. J Venom Anim Toxins Incl Trop Dis 23: 21, 2017.

60. Wang PH, Huang BS, Horng HC, Yeh CC and Chen YJ: Wound healing. J Chin Med Assoc 81: 94-101, 2018.

61. Sorg H, Tilkorn DJ, Hager S, Hauser J and Mirastschijski U: Skin wound healing: An update on the current knowledge and concepts. Eur Surg Res 58: 81-94, 2017.

62. Clark RAF: Wound repair: Overview and general considerations. In: Clark RAF (ed): The molecular, cellular biology of wound repair, Plenum Press, New York, pp3-55, 1996.

63. Martin P and Nunan R: Cellular and molecular mechanisms of repair in acute and chronic wound healing. Br J Dermatol 173 370-378, 2015.

64. Cui N, Hu M and Khalil RA: Biochemical and biological attributes of matrix metalloproteinases. Prog Mol Biol Transl Sci 147: 1-73, 2017.

65. Greaves NS, Ashcroft KJ, Baguneid M and Bayat A: Current understanding of molecular and cellular mechanisms in fibroplasia and angiogenesis during acute wound healing. J Dermato Sci 72: 206-217, 2013.

66. Caley MP, Martins VL and O'Toole EA: Metalloproteinases and wound healing. Adv Wound Care (New Rochelle) 4: 225-234 2015.

67. Krampert M, Bloch W, Sasaki T, Bugnon P, Rülicke T, Wolf E, Aumailley M, Parks WC and Werner S: Activities of the matrix metalloproteinase stromelysin-2 (MMP-10) in matrix degradation and keratinocyte organization in wounded skin. Mol Biol Cell 15: 5242-5254, 2004.

68. Matziari M, Dive V and Yiotakis A: Matrix metalloproteinase 11 (MMP-11; stromelysin-3) and synthetic inhibitors. Med Res Rev 27: 528-552, 2007.

69. Gomis-Rüth FX: Structural aspects of the metzincin clan of metalloendopeptidases. Mol Biotechnol 24: 157-202, 2003.

70. Subramanian S, MacKinnon SL and Ross NW: A comparative study on innate immune parameters in the epidermal mucus of various fish species. Comp Biochem Physiol B Biochem Mol Biol 148: 256-263, 2007

71. Franta Z, Vogel H, Lehmann R, Rupp O, Goesmann A and Vilcinskas A: Next generation sequencing identifies five major classes of potentially therapeutic enzymes secreted by Lucilia sericata medical maggots. Biomed Res Int 2016 8285428, 2016.

72. Valachova I, Majtan T, Takac P and Majtan J: Identification and characterisation of different proteases in Lucilia sericata medicinal maggots involved in maggot debridement therapy. J Appl Biomed 12: 171-177, 2014.

73. Tasoulis $\mathrm{T}$ and Isbister GK: A review and database of snake venom proteomes. Toxins (Basel) 9: pii: E290, 2017.

74. Chambers L, Woodrow S, Brown AP, Harris PD, Phillips D, Hall M, Church JC and Pritchard DI: Degradation of extracellular matrix components by defined proteinases from the greenbottle larva Lucilia sericata used for the clinical debridement of non-healing wounds. Br J Dermatol 148: 14-23, 2003.

75. Polakovicova S, Polák S, Kuniaková M, Čambal M Caplovičová M, Kozánek M, Danišovič L and Kopáni M: The effect of salivary gland extract of Lucilia sericata maggots on human dermal fibroblast proliferation within collagen/hyaluronan membrane in vitro: Transmission electron microscopy study. Adv Skin Wound Care 28: 221-226, 2015

76. Li PN, Li H, Zhong LX, Sun Y, Yu LJ, Wu ML, Zhang LL, Kong QY, Wang SY and Lv DC: Molecular events underlying maggot extract promoted rat in vivo and human in vitro skin wound healing. Wound Repair Regen 23: 65-73, 2015.

77. van der Plas MJA, van der Does AM, Baldry M, Dogterom-Ballering HC, van Gulpen C, van Dissel JT, Nibbering PH and Jukema GN: Maggot excretions/secretions inhibit multiple neutrophil pro-inflammatory responses. Microbes Infect 9: 507-514, 2007.

78. van der Plas MJ, van Dissel JT and Nibbering PH: Maggot secretions skew monocyte-macrophage differentiation away from a pro-inflammatory to a pro-angiogenic type. PLoS One 4 e8071, 2009.

79. Honda K, Okamoto K, Mochida Y, Ishioka K, Oka M, Maesato K, Ikee R, Moriya H, Hidaka S, Ohtake T, et al: A novel mechanism in maggot debridement therapy: Protease in excretion/secretion promotes hepatocyte growth factor production. Am J Physiol Cell Physiol 301: C1423-C1430, 2011.
80. Andersen AS, Sandvang D, Schnorr KM, Kruse T, Neve S, Joergensen B, Karlsmark T and Krogfelt KA: A novel approach to the antimicrobial activity of maggot debridement therapy. J Antimicrob Chemother 65: 1646-1654, 2010.

81. Margolin L and Gialanella P: Assessment of the antimicrobial properties of maggots. Int Wound J 7: 202-204, 2010

82. Pöppel AK, Kahl M, Baumann A, Wiesner J, Gökçen A, Beckert A, Preissner KT, Vilcinskas A and Franta Z: A Jonah-like chymotrypsin from the therapeutic maggot Lucilia sericata plays a role in wound debridement and coagulation. Insect Biochem Mol Biol 70: 138-147, 2016.

83. Mukherjee S, Gomes A and Dasgupta S: Zoo therapeutic uses of snake body parts in folk \& traditional medicine. J Zool Res 1: $1-9,2017$.

84. Shephard KL: Functions for fish mucus. Rev Fish Biol Fisheries 4: 401-429, 1994.

85. Dash S, Das SK, Samal J and Thatoi HN: Epidermal mucus, a major determinant in fish health: A review. Iran J Vet Res 19: $72-81,2018$

86. Sveen L, Timmerhaus GF, Torgersen J, Ytteborg E, Jørgensen SM, Handeland SO, Stefansson SO, Nilsen TO, Calabrese S, Ebbesson LOE, et al: Impact of fish density and specific water flow on skin properties in Atlantic salmon (Salmo salar L.) post-smolts. Aquaculture 464: 629-637, 2016.

87. Al-Hassan JM, Thomson M, Criddle KR, Summers B and Criddle RS: Catfish epidermal secretions in response to threat or injury. Marine Biol 88: 117-123, 1985.

88. Krasnov A, Skugor S, Todorcevic M, Glover KA and Nilsen F: Gene expression in Atlantic salmon skin in response to infection with the parasitic copepod Lepeophtheirus salmonis, cortisol implant, and their combination. BMC Genomics 13: 130, 2012.

89. Schütte A, Lottaz D, Sterchi EE, Stöcker W and Becker-Pauly C Two alpha subunits and one beta subunit of meprin zinc-endopeptidases are differentially expressed in the zebrafish Danio rerio. Biol Chem 388: 523-531, 2007.

90. Nguyen TT, Mobashery S and Chang M: Roles of Matrix Metalloproteinases in Cutaneous Wound Healing. Wound Healing-New insights into Ancient Challenges, 2016.

91. Sterchi EE, Stöcker W and Bond JS: Meprins, membrane-bound and secreted astacin metalloproteinases. Mol Aspects Med 29: 309-328, 2008.

92. Bertenshaw GP, Turk BE, Hubbard SJ, Matters GL, Bylander JE, Crisman JM, Cantley LC and Bond JS: Marked differences between metalloproteases meprin A and B in substrate and peptide bond specificity. J Biol Chem 276: 13248-13255, 2001.

93. Kruse MN, Becker C, Lottaz D, Köhler D, Yiallouros I Krell HW, Sterchi EE and Stöcker W: Human meprin alpha and beta homo-oligomers: Cleavage of basement membrane proteins and sensitivity to metalloprotease inhibitors. Biochem J 378: 383-389, 2004

94. Sun H, Lou X, Shan Q, Zhang J, Zhu X, Zhang J, Wang Y, Xie Y, Xu N and Liu S: Proteolytic characteristics of cathepsin $\mathrm{D}$ related to the recognition and cleavage of its target proteins. PLoS One 8: e65733, 2013.

95. Wolters BK: Cathepsin L and V in human keratinocytes. J Univ, 2006.

96. Vidak E, Javoršek U, Vizovišek M and Turk B: Cysteine cathepsins and their extracellular roles: Shaping the microenvironment. Cells 8: pii: E264, 2019.

97. Reinheckel T, Hagemann S, Dollwet-Mack S, Martinez E, Lohmüller T, Zlatkovic G, Tobin DJ, Maas-Szabowski N and Peters C: The lysosomal cysteine protease cathepsin L regulates keratinocyte proliferation by control of growth factor recycling. J Cell Sci 118: 3387-3395, 2005.

98. Mason RW: Interaction of lysosomal cysteine proteinases with $\alpha 2$-macroglobulin: Conclusive evidence for the endopeptidase activities of cathepsins B and H. Arch Biochem Bioph 273: 367-374, 1989.

99. Maciewicz RA, Etherington DJ, Kos J and Turk V: Collagenolytic cathepsins of rabbit spleen: A kinetic analysis of collagen degradation and inhibition by chicken cystatin. Coll Relat Res 7: 295-304, 1987

100. Benes P, Vetvicka V and Fusek M: Cathepsin D-many functions of one aspartic protease. Crit Rev Oncol Hematol 68: 12-28, 2008.

101. Cavallo-Medved D, Moin K and Sloane B: Cathepsin B: Basis sequence: Mouse. AFCS Nat Mol Pages 2011: pii: A000508, 2011

102. Krejner A, Litwiniuk M and Grzela T: Matrix metalloproteinases in the wound microenvironment: Therapeutic perspectives. Chronic Wound Care Manag Res 3: 29-39, 2016. 
103. Kim GY, Kim HY, Kim HT, Moon JM, Kim CH, Kang S and Rhim H: HtrA1 is a novel antagonist controlling fibroblast growth factor (FGF) signaling via cleavage of FGF8. Mol Cell Biol 32: 4482-4492, 2012.

104. Meyer-Hoffert U and Schröder JM: Epidermal proteases in the pathogenesis of rosacea. J Investig Dermatol Symp Proc 15 16-23, 2011.

105. Kim SK, Park PJ, Kim JB and Shahidi F: Purification and characterization of a collagenolytic protease from the filefish, Novoden modestrus. J Biochem Mol Biol 35: 165-171, 2002.

106. Coughlin SR: Thrombin signalling and protease-activated receptors. Nature 407: 258-264, 2000.

107. Perona JJ and Craik CS: Structural basis of substrate specificity in the serine proteases. Protein Sci 4: 337-360, 1995.

108. Rawlings AV and Voegeli R: Stratum corneum proteases and dry skin conditions. Cell Tissue Res 351: 217-235, 2013.

109. Gutiérrez JM, Escalante T, Rucavado A, Herrera C and Fox JW: A Comprehensive view of the structural and functional alterations of extracellular matrix by snake venom metalloproteinases (SVMPs): Novel perspectives on the pathophysiology of envenoming. Toxins (Basel) 8: pii: E304, 2016.

110. Kini RM and Koh CY: Metalloproteases affecting blood coagulation, fibrinolysis and platelet aggregation from snake venoms: Definition and nomenclature of interaction sites. Toxins (Basel) 8: pii: E284, 2016.

111. Silva MB, Schattner M, Ramos CR, Junqueira-de-Azevedo IL, Guarnieri MC, Lazzari MA, Sampaio CA, Pozner RG, Ventura JS, Ho PL and Chudzinski-Tavassi AM: A prothrombin activator from Bothrops erythromelas (jararaca-da-seca) snake venom: Characterization and molecular cloning. Biochem J 369 : 129-139, 2003.

112. Sanchez EF, Richardson M, Gremski LH, Veiga SS, Yarleque A, Niland S, Lima AM, Estevao-Costa MI and Eble JA: Data for a direct fibrinolytic metalloproteinase, barnettlysin-I from Bothrops barnetti (barnett(,)s pitviper) snake venom with anti-thrombotic effect. Data Brief 7: 1609-1613, 2016.

113. Kamiguti AS: Platelets as targets of snake venom metalloproteinases. Toxicon 45: 1041-1049, 2005

114. Howes JM, Kamiguti AS, Theakston RD, Wilkinson MC and Laing GD: Effects of three novel metalloproteinases from the venom of the West African saw-scaled viper, Echis ocellatus on blood coagulation and platelets. Biochim Biophys Acta 1724: 194-202, 2005.

115. Fernandes CM, Zamuner SR, Zuliani JP, Rucavado A Gutiérrez JM and Teixeira Cde F: Inflammatory effects of BaP1 a metalloproteinase isolated from Bothrops asper snake venom: Leukocyte recruitment and release of cytokines. Toxicon 47 549-559, 2006.

116. Silva A, Gunawardena P, Weilgama D, Maduwage K and Gawarammana I: Comparative in-vivo toxicity of venoms from South Asian hump-nosed pit vipers (Viperidae: Crotalinae: Hypnale). BMC Res Notes 5: 471, 2012.

117. Mariano-Oliveira A, Coelho ALJ, Terruggi $\mathrm{CH}$, Selistre-de-Araújo HS, Barja-Fidalgo C and De Freitas MS Alternagin- $\mathrm{C}$, a nonRGD-disintegrin, induces neutrophil migration via integrin signaling. Eur J Biochem 270: 4799-4808, 2003

118. Silva CA, Zuliani JP, Assakura MT, Mentele R, Camargo ACM Teixeira CFP and Serrano SMT: Activation of $\alpha \mathrm{M} \beta 2$-mediated phagocytosis by HF3, a P-III class metalloproteinase isolated from the venom of Bothrops jararaca. Biochem Biophys Res Commun 322: 950-956, 2004.

119. Tseng YL, Lee CJ and Huang TF: Effects of a snake venom metalloproteinase, triflamp, on platelet aggregation, platelet-neutrophil and neutrophil-neutrophil interactions: Involvement of platelet GPIbalpha and neutrophil PSGL-1. Thromb Haemost 91: 315-324, 2004.

120. Bernardes CP, Menaldo DL, Camacho E, Rosa JC, Escalante T, Rucavado A, Lomonte B, Gutiérrez JM and Sampaio SV: Proteomic analysis of Bothrops pirajai snake venom and characterization of BpirMP, a new P-I metalloproteinase. J Proteomics 80: 250-267, 2013

121. Zigrino P, Kamiguti AS, Eble J, Drescher C, Nischt R, Fox JW and Mauch C: The reprolysin jararhagin, a snake venom metalloproteinase, functions as a fibrillar collagen agonist involved in fibroblast cell adhesion and signaling. J Biol Chem 277: 40528-40535, 2002.

122. Costa ÉP and Santos MF: Jararhagin, a snake venom metalloproteinase-disintegrin, stimulates epithelial cell migration in an in vitro restitution model. Toxicon 44: 861-870, 2004.
123. Cominetti MR, Terruggi $\mathrm{CH}$, Ramos OH, Fox JW, Mariano-Oliveira A, De Freitas MS, Figueiredo CC, Morandi V and Selistre-de-Araujo HS: Alternagin-C, a disintegrin-like protein, induces vascular endothelial cell growth factor (VEGF) expression and endothelial cell proliferation in vitro. J Biol Chem 279: 18247-18255, 2004.

124. SchattnerM,Fritzen M, Ventura JdeS, de Albuquerque ModestoJC, Pozner RG, Moura-da-Silva AM and Chudzinski-Tavassi AM: The snake venom metalloproteases berythractivase and jararhagin activate endothelial cells. Biol Chem 386: 369-374, 2005.

125. Siigur E, Tõnismägi K, Trummal K, Samel M, Vija H, Subbi J and Siigur J: Factor X activator from Vipera lebetina snake venom, molecular characterization and substrate specificity. Biochim Biophys Acta 1568: 90-98, 2001.

126. Markland FS, Kettner C, Schiffman S, Shaw E, Bajwa SS, Reddy KN, Kirakossian H, Patkos GB, Theodor I and Pirkle H: Kallikrein-like activity of crotalase, a snake venom enzyme that clots fibrinogen. Proc Natl Acad Sci USA 79: 1688-1692, 1982.

127. Zhang Y, Wisner A, Xiong Y and Bon C: A novel plasminogen activator from snake venom. Purification, characterization, and molecular cloning. J Biol Chem 270: 10246-10255, 1995.

128. Serrano SM, Matos MF, Mandelbaum FR and Sampaio CA Basic proteinases from Bothrops moojeni (caissaca) venom-I Isolation and activity of two serine proteinases, MSP 1 and MSP 2, on synthetic substrates and on platelet aggregation. Toxicon 31: 471-481, 1993.

129. Frykberg RG and Banks J: Challenges in the treatment of chronic wounds. Adv Wound Care (New Rochelle) 4: 560-582, 2015.

130. Telgenhoff D and Shroot B: Cellular senescence mechanisms in chronic wound healing. Cell Death Differ 12: 695-698, 2005.

131. Lumbers M: Pressure ulcers: An overview of risk. Br J Nurs 26: S49-S50, 2017.

132. Secretariat MA: Management of chronic pressure ulcers: An evidence-based analysis. Ont Health Technol Assess Ser 9: $1-203,2009$

133. Comerota A and Lurie F: Pathogenesis of venous ulcer. Semin Vasc Surg 28: 6-14, 2015

134. Mannello F and Raffetto JD: Matrix metalloproteinase activity and glycosaminoglycans in chronic venous disease: The linkage among cell biology, pathology and translational research. Am J Transl Res 3: 149-158, 2011.

135. van der Plas MJ, Baldry M, van Dissel JT, Jukema GN and Nibbering PH: Maggot secretions suppress pro-inflammatory responses of human monocytes through elevation of cyclic AMP. Diabetologia 52: 1962-1970, 2009.

136. Wei OY, Xavier R and Marimuthu K: Screening of antibacterial activity of mucus extract of snakehead fish, Channa striatus (Bloch). Eur Rev Med Pharmacol Sci 14: 675-681, 2010.

137. Jhamb S, Vangaveti VN and Malabu UH: Genetic and molecular basis of diabetic foot ulcers: Clinical review. J Tissue Viability 25: 229-236, 2016.

138. Su N, Tong N, Du L, Wu B and Xu T: Heparin and related substances for treating diabetic foot ulcers. Cochrane Database Syst Rev 2017: CD011087, 2017.

139. Bruhn-OlszewskaB,Korzon-Burakowska A,Gabig-CiminskaM, Olszewski P, Wegrzyn A and Jakóbkiewicz-Banecka J: Molecular factors involved in the development of diabetic foot syndrome. Acta Biochim Pol 59: 507-513, 2012.

140. Blakytny R and Jude EB: Altered molecular mechanisms of diabetic foot ulcers. Int J Low Extrem Wounds 8: 95-104, 2009.

141. Patel S, Srivastava S, Singh MR and Singh D: Mechanistic insight into diabetic wounds: Pathogenesis, molecular targets and treatment strategies to pace wound healing. Biomed Pharmacother 112: 108615, 2019.

142. Sherman RA: Maggot therapy for treating diabetic foot ulcers unresponsive to conventional therapy. Diabetes Care 26: 446-451, 2003.

143. Pasha M, Husin RA and Hassan S: The influence of oral and topical Channa striatus on laparotomy wound healing in malnourished wistar rats. Int J Pharm Pharm Sci Invent 4: 37-41, 2015.

144. Anish S: Skin substitutes in dermatology. Indian J Dermatol Venereol Leprol 81: 175-178, 2015.

145. Kordestani SS: Chapter 5-wound care management. In: Atlas of wound healing. Kordestani SS (ed). Elsevier, pp31-47, 2019.

146. Sun BK, Siprashvili Z and Khavari PA: Advances in skin grafting and treatment of cutaneous wounds. Science 346: 941-945, 2014

147. Knapik A, Hegland N, Calcagni M, Althaus M, Vollmar B, Giovanoli $\mathrm{P}$ and Lindenblatt N: Metalloproteinases facilitate connection of wound bed vessels to pre-existing skin graft vasculature. Microvasc Res 84: 16-23, 2012. 
148. Park YJ, Lee JW, Chong Y and Park TH: Botulinum toxin A increases allograft tolerance in an experimental transplantation model: A preliminary study. Biosci Rep 38: pii: BSR20171721, 2018

149. Kucukkaya D, Irkoren S, Ozkan S and Sivrioglu N: The effects of botulinum toxin A on the wound and skin graft contraction. J Craniofac Surg 25: 1908-1911, 2014.

150. Boyko TV, Longaker MT and Yang GP: Review of the current management of pressure ulcers. Adv Wound Care (New Rochelle) 7: 57-67,2018.

151. Ma H, O'Donnell TF Jr, Rosen NA and Iafrati MD: The real cost of treating venous ulcers in a contemporary vascular practice. J Vasc Surg Venous Lymphat Disord 2: 355-361, 2014.

152. Ford CN, Reinhard ER, Yeh D, Syrek D, De Las Morenas A Bergman SB, Williams S and Hamori CA: Interim Analysis of a Prospective, Randomized Trial of Vacuum-Assisted Closure Versus the Healthpoint System in the Management of Pressure Ulcers. Ann Plast Surg 49 (1): 55-61, 2002.

153. Yaakobi T, Cohen-Hadar N, Yaron H, Hirszowicz E, Simantov Y, Bass A and Freeman A: Wound debridement by continuous streaming of proteolytic enzyme solutions: Effects on experimenta chronic wound model in porcin. Wounds 19: 192-200, 2007.

154. Smith \& Nephew, Inc.: Enzymatic debridement with collagenase SANTYL ${ }^{\circledR}$ Ointment, 2014

155. Giudice G, Filoni A, Maggio G, Bonamonte D and Vestita M: Cost analysis of a novel enzymatic debriding agent for management of burn wounds. Biomed Res Int 2017: 9567498, 2017.

156. Gorecki $\mathrm{M}$ and Toren A: Debriding composition from bromelain and methods of production thereof, Patent Appl Publ, 2005.

157. Klein GKV and Houck JC: Hydrolytic enzyme material, 1980.

158. Niehaus F, Eck J, Schulze R and Krohn M: Proteasa para el acondicionamiento de heridas y el cuidado de la piel. Brain Biotechnol Res Inf Netw, 2012.

159. Niehaus F, Eck J, Schulze R and Krohn M: Protease for wound conditioning and skin care. Brain Biotechnol Res Inf Netw, 2012

160. Rosenberg L: Aparato y procedimientos para su uso en escarotomía enzimática en síndrome de compartimento inducido por quemaduras. MediWound, 2012.

161. Freeman A, Hirszowicz E and Be'eri-lipperman M: Apparatus and method for the enzymatic debridement of skin lesions, Ramot At Tel-Aviv Univ, 2012.

162. Yaakobi T, Roth D, Chen Y and Freeman A: Streaming of proteolytic enzyme solutions for wound debridement: A feasibility study. Wounds 16: 201-205, 2004.

163. Rodeheaver G, Edgerton MT, Elliott MB, Kurtz LD and Edlich RF: Proteolytic enzymes as adjuncts to antibiotic prophylaxis of surgical wounds. Am J Surg 127: 564-572, 1974.

164. Gao M, Nguyen TT, Suckow MA, Wolter WR, Gooyit M, Mobashery S and Chang M: Acceleration of diabetic wound healing using a novel protease-anti-protease combination therapy. Proc Natl Acad Sci USA 112: 15226-15231, 2015.

165. Gutiérrez-Fernández A, Fueyo A, Folgueras AR, Garabaya C, Pennington CJ, Pilgrim S, Edwards DR, Holliday DL, Jones JL, Span PN, et al: Matrix metalloproteinase-8 functions as a metastasis suppressor through modulation of tumor cell adhesion and invasion. Cancer Res 68: 2755-2763, 2008.

166. Hartenstein B, Dittrich BT, Stickens D, Heyer B, Vu TH, Teurich S, Schorpp-Kistner M, Werb Z and Angel P: Epidermal development and wound healing in matrix metalloproteinase 13-deficient mice. J Invest Dermatol 126: 486-496, 2006.

167. Kudo Y, Iizuka S, Yoshida M, Tsunematsu T, Kondo T, Subarnbhesaj A, Deraz EM, Siriwardena SB, Tahara H, Ishimaru N, et al: Matrix metalloproteinase-13 (MMP-13) directly and indirectly promotes tumor angiogenesis. J Biol Chem 287: 38716-38728, 2012.
168. Rohani MG and Parks WC: Matrix remodeling by MMPs during wound repair. Matrix Biol 44-46: 113-121, 2015.

169. Thirkettle S, Decock J, Arnold H, Pennington CJ, Jaworski DM and Edwards DR: Matrix Matrix metalloproteinase 8 (collagenase 2) induces the expression of interleukins 6 and 8 in breast cancer cells. J Biol Chem 288: 16282-16294, 2013

170. Utz ER, Elster EA, Tadaki DK, Gage F, Perdue PW, Forsberg JA, Stojadinovic A, Hawksworth JS and Brown TS: Metalloproteinase expression is associated with traumatic wound failure. J Surg Res 159: 633-639, 2010

171. Yamamoto K, Okano H, Miyagawa W, Visse R, Shitomi Y, Santamaria S, Dudhia J, Troeberg L, Strickland DK, Hirohata S and Nagase H: MMP-13 is constitutively produced in human chondrocytes and co-endocytosed with ADAMTS-5 and TIMP-3 by the endocytic receptor LRP1. Matrix Biol 56: 57-73, 2016.

172. Motrescu ER, Blaise S, Etique N, Messaddeq N, Chenard MP, Stoll I, Tomasetto C and Rio MC: Matrix metalloproteinase-11/stromelysin-3 exhibits collagenolytic function against collagen VI under normal and malignant conditions. Oncogene 27: 6347-6355, 2008

173. Pittayapruek P, Meephansan J, Prapapan O, Komine M and Ohtsuki M: Role of matrix metalloproteinases in photoaging and photocarcinogenesis. Int J Mol Sci 17: pii: e868, 2016.

174. Saarialho-Kere UK, Pentland AP, Birkedal-Hansen H, Parks WC and Welgus HG: Distinct populations of basal keratinocytes express stromelysin-1 and stromelysin-2 in chronic wounds. J Clin Invest 94: 79-88, 1994.

175. Sato T, Nomura K and Hashimoto I: Expression of collagenase and stromelysin in skin fibroblasts from recessive dystrophic epidermolysis bullosa. Arch Dermatol Res 287: 428-433, 1995.

176. Kren L, Goncharuk V, Krenová Z, Stratil D, Hermanová M, Skricková J, Sheehan CE and Ross JS: Expression of matrix metalloproteinases 3,10 and 11 (stromelysins 1,2 and 3) and matrix metalloproteinase 7 (matrilysin) by cancer cells in non-small cell lung neoplasms. Clinicopathologic studies. Cesk Patol 42: 16-19, 2006

177. Page-McCaw A, Ewald AJ and Werb Z: Matrix metalloproteinases and the regulation of tissue remodelling. Nat Rev Mol Cell Biol 8: 221-233, 2007

178. Purcell WT and Hidalgo M: Matrix metalloproteinase inhibitors in cancer therapy. In: Proteases in tissue remodelling of lung and heart. Lendeckel U and Hooper NM (eds). Springer US, Boston, MA, pp75-118, 2003

179. Herouy Y: The role of matrix metalloproteinases (MMPs) and their inhibitors in venous leg ulcer healing. Phlebolymphology 44 231-243, 2004

180. Lagente V, Manoury B, Nenan S, Le Quement C, Martin-Chouly C and Boichot E: Role of matrix metalloproteinases in the development of airway inflammation and remodeling. Braz J Med Bio Res 38: 1521-1530, 2005

181. van Marion MMH: Matrix metalloproteinases and collagen remodeling. A Literature Review, 2006

182. Tewari A, Grys K, Kollet J, Sarkany R and Young AR: Upregulation of MMP12 and its activity by UVA1 in human skin: potential implications for photoaging. J Invest Dermatol 134: 2598-2609, 2014. 